\title{
Distancing is Closer than Ever
}

\author{
Steven M. Cohen • Ari Y. Kelman
}

Received: 5 March 2010/Accepted: 4 July 2010/Published online: 25 August 2010

(C) The Author(s) 2010. This article is published with open access at Springerlink.com

\begin{abstract}
A concluding word on the exchange on the Distancing Hypothesis.
\end{abstract}
Keywords The distancing hypothesis

There is no imminent danger that American Jews will abandon their concern with Israel or with Soviet Jewry. On the contrary, much of organized Jewish life today is built around support for Israel and world Jewry. But there is a danger that a conception of American Judaism will develop that will make such support increasingly meaningless and eventually lead to its diminution. Such a process may, in fact, already be taking place (Liebman 1987, pp. 43-44).

It is gratifying to have so many people read and respond to our original article for the wider public (Beyond Distancing), the paper that initiated very careful scholarly analysis in an article by our colleagues at Brandeis. These two papers, in turn, spawned the exchange and the nearly two dozen comments presented in this very lively and informative issue of Contemporary Jewry.

We are truly gratified by the vibrant discourse about American Jews and Israel in these pages. And we are grateful to our many colleagues who contributed their thoughts; in particular we thank Samuel Heilman for his indefatigable efforts to make this issue of Contemporary Jewry a reality. We appreciate not only the responses themselves, but the collegial tone taken by all but one of them.

S. M. Cohen $(\bowtie)$

Hebrew Union College-Jewish Institute of Religion, New York, NY, USA

e-mail: steve34nyc@aol.com

A. Y. Kelman

University of California, Davis, CA, USA

e-mail: aykelman@ucdavis.edu 
Whatever the disagreements among us, one conclusion emerges from these contributions quite clearly and, we think, unanimously: Collectively, we are just scratching the surface of our understanding of the relationship between American Jews and Israel. Even with all of the scholarly dedication to the topic at hand, this issue of Contemporary Jewry will hardly be the final word in this discussion.

To be clear, for our part, we heartily agree with the criticisms of the limitations of our concepts, indicators, sample, and analysis. We agree with those who say that the survey evidence alone is inadequate to prove our contention that non-Orthodox Jews have been growing more distant from Israel. For sure, the hard evidence on the matter is inconclusive. We never said, and still do not say, otherwise.

However, we do contend that a full sweep of the available evidence-embracing the work of historians of American Jewry, analysts of other survey data sets, and qualitative interviews and ethnographic observation, taken together-points very powerfully in the direction we tried to communicate in "Beyond Distancing." To wit: Among non-Orthodox Jews, younger people are indeed less attached to Israel, no matter which measure is used; moreover, this age-related pattern is indicative of a long-seated distancing from Israel. We arrived at our conclusion, one which coalesced only after the last several years, informed by several major currents in the social scientific literature, among them:

- The detachment from fixed identities of all sorts-in American politics, religion, consumer behavior, etc.

- Declining indicators of American Jews' ethnic cohesion, a strong predictor of Israel attachment. Among the most critical: in-marriage and in-group friendship.

- Weakening centrality of formal Jewish organizations (synagogues, Federations, etc.) in conceptualizing and organizing Jewish life.

- American Jews' re-conceptualization of Judaism and Jewish identity toward an emphasis on the construction of meaning, on the Sovereign Jewish Self, or as an expression of what Sklare and Liebman referred to as "personalism."

- Qualitative (and some new quantitative) research about younger American Jews which reinforces our perception of distancing from Israel not only among younger Jews in general, but among the more Jewishly engaged "leaders" outside of Orthodoxy.

Perhaps most critically, we were (and remain) aware of the variety of evidence, analyses and insights offered by numerous colleagues in several disciplines. The most recent testimony of this trend among our scholarly community is contained within these very pages. Among the contributors, about half our colleagues understandably (and perhaps wisely) refrained from venturing a learned opinion in favor of either the Distancing Hypothesis or the Stability Perspective. The other commentators, though, did in fact offer a view on the matter, albeit often qualified and contextualized with very legitimate critique of our work (and our colleagues). We offer the core of their assessments as follows:

Morton Weinfeld: "I agree with the Cohen-Kelman position. While in iconic Jewish joke terms 'they are both right,' in fact I suspect that the Cohen-Kelman position is more accurately capturing the zeitgeist of the moment. There is a bi-modal community emerging, and the non-Orthodox segment is likely the one 
with a modest but steady distancing going on, which depends on Israeli policies, etc., but even more on a general assimilationist drift."

Jack Wertheimer: "Based on a range of sources, there is ample evidence of a general decline in American Jewish identification with Israel, a pattern especially evident today among younger Jews in their twenties and thirties. Survey findings alone are of only limited utility in capturing the underlying social reality."

Chaim Waxman: "Although the arguments of both Cohen and Kelman and Sasson and colleagues are well presented and are based on careful analyses of the data each utilized, the Cohen-Kelman thesis is more convincing because it is supported by a variety of evidence and because its argument with respect to connectedness with Israel fits within a larger framework of patterns of American Jewish identity and identification."

Rela Geffen: "Although I tend to be optimistic about the present and future of the American Jewish community and the persistence of Jewish identity, I was more persuaded by the Cohen and Kelman approach. There is a distancing trend in certain growing segments of the population that should not be ignored."

Sergio Della Pergola: "The unequivocal inference from these cross-sectional cohort data is a gradual weakening over time of the relationship of American Jews toward Israel. ... These [data] point to an unmistakable blurring among the younger of the strong sense of interest, affective involvement, responsibility and caring that American Jewry have historically demonstrated toward the State of Israel and its Jewish community."

Bruce Phillips: "Cohen and Kelman contend that because the American Jewish Committee surveys used by Sasson, Kadushin, and Saxe are limited only to 'those who say that their religion is Jewish,' these studies miss the growing population of Jews 'who identify as Jewish, but see their religion as "none." Were these secular Jews to be included in the AJC studies, Sasson, Kadushin, and Saxe would have found a more pronounced distancing."

Based on my own intermarriage research, I agree with the Cohen-Kelman critique, but also find that the life-course explanation put forward by Sasson, Kadushin, and Saxe has merit with regard to Jews-by-religion.

Alex Pomson: "If schools mirror society, as widely claimed by sociologists of education, then the approach to teaching about Israel in the Jewish day schools of North America closely reflects the social situation depicted by Cohen and Kelman in their Beyond Distancing research. This is the impression that emerges from two recent studies of the practices and pedagogy of Israel education in more than three hundred North American non-haredi Jewish day schools."

Ariela Keysar: "An analysis of the AJIS, 2001 reveals that cultural Jews, often classified as Jews of no religion, have weak connections to Israel. Given the composition of the current American Jewish population and considering high intermarriage rates, that segment of the population is likely to grow, thus distancing American Jewry further from Israel."

Based in part (and only in part) upon our original 2007 paper; in part upon wider trends in American society, religion, and Judaism; and in part upon the work of our many colleagues, we believe it is fair to conclude: The "Distancing from Israel 
Hypothesis," when applied to non-Orthodox American Jews, is an accurate reading of recent and contemporary trends.

Open Access This article is distributed under the terms of the Creative Commons Attribution Noncommercial License which permits any noncommercial use, distribution, and reproduction in any medium, provided the original author(s) and source are credited.

\section{Reference}

Liebman, Charles S. 1987. The quality of American Jewish life-two views: a grim outlook. New York: American Jewish Committee (AJC).

\section{Author Biographies}

Steven M. Cohen is Research Professor of Jewish Social Policy at the Hebrew Union College-Jewish Institute of Religion and Director of the Berman Jewish Policy Archive at NYU Wagner.

Ari Y. Kelman is Assistant Professor of American Studies at the University of California at Davis. 